ISSN: 2536-5339

\title{
Mega Spor Organizasyonları Sporcularının Gözüyle \\ Olimpik Hareket ve Olimpizm Algıları
}

\author{
Melike ESENTAŞ ${ }^{1} \quad$ Pınar GÜZEL ${ }^{1} \quad$ Selhan ÖZBEY $^{1} \quad$ Ertan ÇELIK $^{2}$ \\ ${ }^{1}$ Manisa Celal Bayar Üniversitesi Spor Bilimleri Fakültesi, MANISA \\ ${ }^{2}$ Batman Üniversitesi Sosyal Bilimler Enstitüsü, Rekreasyon Yönetimi, BATMAN
}

Künye: Esentaş, M., Güzel, P., Özbey, S. ve Çelik, E. (2018). Mega Spor Organizasyonları Sporcularının Gözüyle Olimpik Hareket ve Olimpizm Algıları. Gaziantep Üniversitesi Spor Bilimleri Dergisi, 3(4): 32-47.

\section{Öz}

Olimpik anlayış aslında sporun herkes için olduğu fikrinden ortaya çıkmaktadır ve profesyonel sporcuların sahip oldukları bakış açısı toplumsal değerlere bir ayna tutmaktadır. Bu bağlamda araştırmanın amacı; mega spor etkinliklerine katılan elit sporcuların olimpik hareket ve olimpizm algılarıyla ilgili görüşlerinin değerlendirilmesidir. $\mathrm{Bu}$ çalışma, nitel araştırma desenlerinden "olgu bilim" deseni kapsamında yürütülmüştür. Olgu bilim çalışmalarında genellikle belli bir olguya ilişkin bireysel algıların veya perspektiflerin ortaya çıkarılması ve yorumlanması amaçlanır (Yıldırım \& Şimşek, 2005). Araştırmanın çalışma grubunu Güreş, Taekwando, Karate-Do ve Judo branşlarından oluşan Olimpiyat Oyunları, Dünya ve Avrupa Şampiyonaları düzeyinde mega spor organizasyonlarına katılan 8 (sekiz) sporcu oluşturmaktadır. Çalışma grubunun belirlenmesi aşamasında, katılımcıların spor alanında düzenlenen en üst düzeyde organizasyonlara katılım göstermeleri sebebiyle amaçlı örneklem yöntemi tercih edilmiştir. Araştırma da veri toplama aracı olarak görüşme yöntemi türlerinden yarı yapılandırımış görüşme tekniği kullanılmıştır. Araştırma verilerinin çözümlenmesinde betimsel analiz ve içerik analizi teknikleri kullanılmıştır. Araştırma da; Kodlayıcılar arasındaki uyum olarak güvenirlik hesaplaması sonucunda (Kappa istatistiği) $r=0.84$ bulunmuştur. Yapılan içerik analizi sonucunda elde edilen verilere göre mega spor organizasyonlarına katılan sporcuların algıları "Sportif başarıyı etkileyen faktörler", "Mega spor organizasyonları kazanımları", "Mega spor organizasyonları katılımcılarının öz-farkındalık algıları" ve "Olimpik hareket ve Olimpizm anlayışının sürdürülebilirliği" şeklinde dört tema altında toplandığı görülmüştür. Sonuç olarak; Olimpik Hareket ve Olimpizm düşüncesinin değişen ve gelişen anlamının değerlendirilmesi ve bu düşüncenin yaygınlaştırılması spor kültürünün oluşumunda rol oynamaktadır. Bu bakımından Türkiye'de spor kültürünün sürdürülebilir bir yaşam biçimi haline dönüşmesini sağlamada ülkemizi temsil eden milli sporcuların topluma ışık tutması gerekliliği ve önemi görülmektedir.

Anahtar Kelimeler: Mega spor organizasyonları, sporcu, olimpik hareket, olimpizm

\section{Orijinal Makale}

Yayın Bilgileri

Gönderi Tarihi: 01.11.2018

Kabul Tarihi: 20.11.2018

Yayın Tarihi: 28.12.2018

Sorumlu Yazar

e-mail:

melike.esentas@windowslive.com

DOI: $10.31680 /$ gaunjss.477512 


\section{Olympic Movement and Olympism Perceptions from the Eyes of Athletes in Mega Sports Events}

\begin{abstract}
The Olympic understanding is in fact based on the idea that the sports is for everyone, and the perspective of the professional athletes holds a mirror to the social values. In this regard, the purpose of this study is to evaluate the opinions of elite athletes who participate in mega sports events regarding Olympic movement and olympism perceptions. This study was carried out within the scope of the "phenomenology" design being among the qualitative research designs. The purpose of case studies is generally intended to reveal and interpret individual perceptions or perspectives about a particular phenomenon (Yıldırım \& Şimşek, 2005). The research population of the study is composed of 8 (eight) athletes who participate in mega sports events from the branches of Wrestling, Taekwondo, Karate-Do and Judo at the level of Olympic Games, World and European Championships. In selection of this study group, since it is made up of the athletes participating in the highest level events organized in the sports field, sample selection has played a role. Semistructured interview technique was used as the data collection tool in the research. Descriptive analysis and content analysis techniques were used to analyze the research data. In the research, as a result of the reliability calculation as the compliance between encoders, (Kappa statistic) was found as $r=0.84$. Data obtained after the interviews were analyzed with descriptive method and then coded under appropriate themes. Following the content analysis, the perceptions of the athletes participating in mega sports events have been observed to be collected under four topics as "Factors affecting athletic success", "Gains of mega sports events", "Selfawareness perceptions of the participants of mega sports events" and "Sustainability of Olympic movement and olympism understanding". In conclusion, assessment of the changing and evolving meaning of the Olympic Movement and Olympism thought and its dissemination plays a role in the formation of sports culture. In this sense, it is observed that the national athletes representing our country should enlighten the society in ensuring transformation of sports culture in Turkey into a sustainable lifestyle.
\end{abstract}

Key Words: Mega Sports Events, Athlete, Olympic Movement, Olympism

\section{Original Article}

\section{Article Info}

Received: 01.11.2018

Accepted: 20.11.2018

Published: 28.12.2018

\section{Corresponding Author \\ e-mail: \\ melike.esentas@windowslive.com}

\section{Giriş}

Spor sosyal bir olgu olarak bireylerin düzenli ya da düzensiz yaptıkları eğitim aracı, dil, din, ırk ayrımı yapmaksızın evrensel bir kültürün parçasıdır. Kerkez'e (2012) göre spor klasik pedagojide bedenin, ruhun ve zihnin eğitim aracıdır. Spor yapan ve yapmayan çocuklar ile erkekler ve kadınlar arasındaki farklara yönelik yapılan araştırmaların (Bayar, 2003; Bora, 2012) ortak görüşü spor bireyin; beden sağlığına, ruh sağlığına, zihinsel-ahlaki-kişilik gelişimine, olgunlaşmasına, özgüven sahibi olmasına, sosyalleşmesine, algı gelişimine, statü sahibi olması gibi olumlu katkılarını tespit etmişlerdir.

Beden becerisi ile birlikte insan aklının ve kişiliğinin gelişmesini hedef alan ve böylece insanın tüm niteliklerinin simetrik biçim ve uyum içinde gelişimini hedefleyen bir hayat felsefesi olan Olimpizm, çağımızın en önde gelen olgularından biridir. 
Olimpizm ne bir din, ne bir sosyal doktrin, ne de sosyal veya ekonomik bir sistemdir. Olimpizm bir ruh halidir, hayat tarzıdır, insanlık görüşüdür (TMOK, 2002).

Özbey ve Güzel'in (2009) yapmış olduğu bir çalışmada da tanımlandığı üzere, spor, kültür ve eğitimi bir araya getiren Olimpik Hareket, temelinde insanlığın ileriye gitmesi için gerekli olan değerlerdir. Olimpizm anlayışına dayanan Olimpik Hareket kavramı, 19.yy. sonlarında Avrupa'da ortaya çıkan “Uluslararası Barış Hareketi”nin ve "Uluslararası Spor Hareketi”nin bir parçasıdır (Güzel ve ark., 2009). Olimpik Hareketin amacl; Olimpiyat ruhundaki ve herhangi bir türdeki ayrımcllıtan uzak gerçekleştirilen spor sayesinde gençleri eğiterek daha iyi ve barış dolu bir dünya yaratmaya katkıda bulunmaktır. Bu da dayanışma, adil oyun ve arkadaşlık ruhunu içeren karşılıklı anlayış gerektirmektedir. Olimpik Hareket, Olimpik Antlaşma' yı rehber olarak benimseyen örgütleri, sporcuları ve diğer kişileri IOC'nin otoritesi altında toplar. Olimpik Hareket bu amacı gerçekleştirmek için olanaklarının elverdiği ölçüde tek başına ya da başka örgütlerle işbirliği içinde barışı yaygınlaştırmaya yönelik eylemlerde bulunur (IOC, 2004). İç içe geçmiş beş halkayla simgelenen Olimpik hareketin etkinliği evrensel ve kalıcıdır. Beş kıtayı kucaklamakta ve bütün dünyadan sporcuları büyük bir spor şöleni olan Olimpiyat Oyunlarda bir araya getirerek doruk noktasına ulaşmaktır (Akt. Atalay Noordegraaf, 2017; TMOK, 1988).Uluslararası önem taşıyan ve büyük kitlelere hitap eden, düzenlendiği bölgenin kültürünü yansıtan, devlet kurumları ya da özel kuruluşlar tarafından çeşitli amaçlarla (spor, kültürel, sanatsal, ticari, eğitim vb.) gerçekleştirilen büyük ölçekli etkinlikler mega etkinlik olarak tanımlanmaktadır (Roche, 2000).

Bu araştırmanın amacı da mega spor organizasyonları sporcularının gözüyle olimpik hareket ve olimpizm anlayışının değerlendirilmesidir.

\section{Yöntem}

$\mathrm{Bu}$ çalışma, nitel araştırma desenlerinden biri olan "olgu bilim" deseni kapsamında yürütülmüştür. Olgu bilim çalışmalarında genellikle belli bir olguya ilişkin bireysel algıların veya perspektiflerin ortaya çıkarılması ve yorumlanması amaçlanır (Yıldırım ve Şimşek, 2005). Araştırmanın çalışma grubunu Güreş, Taekwando, Karate-Do ve Judo branşlarından oluşan Olimpiyat Oyunları, Dünya ve Avrupa Şampiyonaları düzeyinde mega spor organizasyonlarına katılan 8 (sekiz) sporcu oluşturmaktadır. 
Araştırma da nitel araştırma yöntemi, veri toplama aracı olarak görüşme yöntemi türlerinden yarı yapılandırılmış görüşme tekniği kullanılmıştır. Görüşme çalışmanın amaçları doğrultusunda bilgi elde etmeye çalışan araştımacı ile katıımcı arasında soru cevaba dayalı etkili ve verimli bilgi elde etme sürecidir. Görüşme, araştırmaya katılanların duygularını, düşüncelerini, izlenimlerini ve tecrübelerini ve söz konusu tecrübelerini ne şekilde anlamlandırdıklarını açıklamayı amaçlamaktadır (Doğanay ve ark., 2012). Görüşme sorularının hazırlanışında ilgili literatür desteği alınmasının ardından, çalışma ve nitel alanda uzman görüşünden yararlanılarak araştırma soruları oluşturulmuştur. Görüşme soruları hazırlanırken ilgili literatür tarandıktan sonra elde edilen verilerden yararlanılarak görüşme soruluları oluşturulmuştur. Daha sonra katılımcılardan elde edilen veriler, Nvivo 10 for Windows (lisansı ürün) programı aracılığıyla kodlanmıştır.

Nitel verilerin çözümlenmesinde, görüşme yapılan katılımcılar alfabetik harflerle $(A, B, P)$ kodlanmıştır. Katıımcı profili ile ilgili bilgiler tablo 1'de verilmiştir. Araştırma verilerinin çözümlenmesinde betimsel analiz ve içerik analizi teknikleri kullanılmıştır. Betimsel analiz; elde edilen verilerin daha önceden belirlenen temalara göre özetlenip yorumlandığı, görüşülen bireylerin görüşlerinin çarpıcı bir biçimde yansıtmak amacıyla sık sık doğrudan alıntıların kullanıldığı ve elde edilen sonuçların neden- sonuç ilişkileri çerçevesinde yorumlandığı analiz tekniğidir (Yıldırım ve Şimşek, 2003). Betimsel analiz tekniği üç etkinlik basamağı (verilerin azaltılması, verilerin sunumu, sonuç çıkarma ve doğrulama) çerçevesinde gerçekleştirilmiştir (Türnüklü, 2000). Verilerin sunumunda, alıntı seçimi için çarpıcılık (farklı görüş), açıklayıcııık (temaya uygunluk), çeşitlilik ve uç örnekler ölçütleri dikkate alınmıştır (Ünver ve ark., 2010). İçerik analizi, en sık rastlanan analiz türlerinden biridir. Toplanan verileri açıklayabilen, ortaya koyabilen kavramlara ulaşılmaya çalışıır (Silverman, 2001). İçerik analizinde yapılan temel işlem, birbirine benzeyen verileri belirli kavramlar ve temalar çerçevesinde bir araya getirmek ve okuyucunun anlayabileceği bir biçimde düzenleyerek yorumlamaktır (Yıldırım ve Şimşek, 2005).

Formlardan elde edilen veriler öncelikle Office programına aktarılmış ve alana ve araştırma yöntemine yönelik alanında uzman 3 kişi tarafından kodlamalar oluşturulmuştur. Ardından kodlar bir araya getirilerek, araştırma bulgularının ana hatlarını oluşturacak temalar (kategoriler) ortaya çıkarılarak betimsel ve içerik analizleri yapılmıştır. İki veya daha fazla kodlayıcının yaptığı değerlendirmeler arasındaki tutarlılı̆ı belirlemek için Cohen'in Kappa istatistiği kullanılmaktadır. 
Fleiss'in kappa katsayısı ikiden fazla sabit sayıda puanlayıcı arasındaki karşılaşıımalı uyuşmanın güvenirliğini ölçen bir istatistik yöntemidir (Cohen ve Swerdlik, 2002). Araştırma da red ve kabul edilen kodlar Cohen kappa formülüne yerleştirilerek hesaplanmıştır.

Kappa katsayısının 0.0 ile. 20 arasında olması, uyumun olmadığı; .21 ile .40 arasında olması, orta düzeyde bir uyumun olduğu; .41 ile .60 arasında olması, çoğunlukla uyumun olduğu; .61 ile .80 arasında olması, önemli düzeyde bir uyumun olduğu; .81 ile 1.00 arasında olması ise çok iyi düzeyde uyum olduğu şeklinde yorumlanmaktadır (Landis ve Koch, 1977). Araştırmada; Kodlayıcırlar arasındaki uyum olarak güvenirlik hesaplaması sonucunda $r=0.84$ bulunmuştur. Bu nedenle hesaplanan değerler, puanlayıcılar arasında çok iyi düzeyde uyum olduğunu göstermektedir

\section{Araştırma Etiği}

$\mathrm{Bu}$ araştırma sürecinde ana etik ilkelerin gerçekleştirilmesine özen ve önem gösterilmiştir. Bu doğrultuda; araştırmacılara çalışma başlangıcında çalışmaya gönüllü olarak katılmalarına ilişkin bilgilendirme yapılarak katıımcıların Bilinçli Onay ilkesi doğrultuda araştırmaya dâhil edilmesi sağlanmıştır. Katılımcıların kişisel bilgileri gizli tutulmuş ve deşifre edilmeyerek" Gizlilik, özel hayata saygı ve zarar vermeme" etik ilkesine dikkat edilmiştir. Ayrıca katılımcılardan elde edilen veriler araştırmada açık-seçik ifade edilerek "Aldatmama, yanıltmama ve verilere sadık kalma" etik ilkesine riayet edilmiştir. 
Tablo 1. Mega spor organizasyonlar katılımcılarının demografik bilgileri

\begin{tabular}{|c|c|c|c|c|c|c|c|c|c|c|c|c|c|c|c|c|c|}
\hline \multirow{2}{*}{ 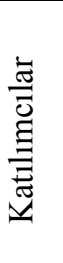 } & \multirow{2}{*}{ 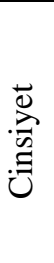 } & \multirow{2}{*}{$\stackrel{\pi}{\pi}$} & \multirow{2}{*}{ 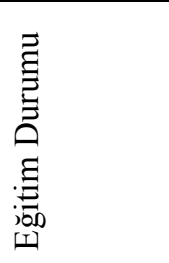 } & \multirow{2}{*}{ 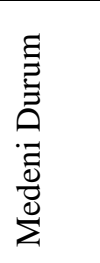 } & \multirow{2}{*}{ 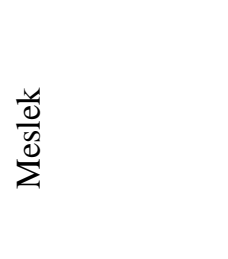 } & \multirow{2}{*}{ 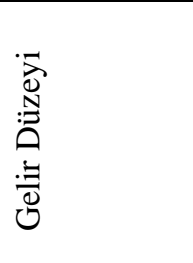 } & \multirow{2}{*}{ 苞 } & \multirow{2}{*}{ 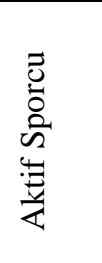 } & \multirow{2}{*}{ 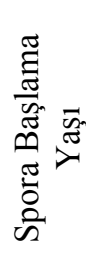 } & \multirow{2}{*}{ 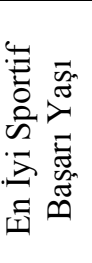 } & \multicolumn{2}{|c|}{$\begin{array}{c}\text { Olimpiyat } \\
\text { Oyunları Başarı }\end{array}$} & \multicolumn{2}{|c|}{$\begin{array}{c}\text { Dünya } \\
\text { Şampiyonaları } \\
\text { Başarınız } \\
\end{array}$} & \multicolumn{2}{|c|}{$\begin{array}{c}\text { Avrupa } \\
\text { Şampiyonaları } \\
\text { Başarınız } \\
\end{array}$} & \multirow[t]{2}{*}{$\begin{array}{c}\text { Spor Kuruluş. } \\
\text { Görev }\end{array}$} \\
\hline & & & & & & & & & & & Yil & Derece & Yil & Derece & Yil & Derece & \\
\hline K1 & $E$ & $18-29$ & Lisansüstü & Bekar & Mili sporcu & $\begin{array}{l}3001 \text { TL ve } \\
\text { üstü }\end{array}$ & Güreş & Evet & 12 & 26 & 2016 & 1 & 2015 & 1 & 2014 & 1 & $\begin{array}{l}\text { TMOK sporcu } \\
\text { komisyonu üyesi }\end{array}$ \\
\hline K2 & $\mathrm{E}$ & $18-29$ & Lisans & Bekar & Mili sporcu & $\begin{array}{l}3001 \text { TL ve } \\
\text { üstü }\end{array}$ & Güreş & Evet & 10 & 27 & 2016 & 2 & 2015 & 1 & 2015 & 1 & $\begin{array}{l}\text { TMOK sporcu } \\
\text { komisyonu üyesi }\end{array}$ \\
\hline K3 & $\mathrm{K}$ & $18-29$ & Lise & Bekar & Mili sporcu & $\begin{array}{c}500-1000 \\
\text { TL }\end{array}$ & Taekwando & Evet & 12 & 20 & - & - & 2016 & 1 & - & - & - \\
\hline K4 & $\mathrm{E}$ & $18-29$ & Lise & Bekar & Mili sporcu & $\begin{array}{c}500-1000 \\
\text { TL }\end{array}$ & Taekwando & Evet & 12 & 17 & - & - & 2016 & 1 & - & - & - \\
\hline K5 & $\mathrm{E}$ & $18-29$ & Lisans & Bekar & $\begin{array}{l}\text { Beden Eğitimi } \\
\text { ve Spor } \\
\text { Öğretmeni }\end{array}$ & $\begin{array}{l}3001 \text { TL ve } \\
\text { üstü }\end{array}$ & Karate-Do & Evet & 10 & 23 & - & - & - & - & 2013 & 1 & - \\
\hline K6 & E & $30-39$ & Lise & Evli & $\begin{array}{l}\text { Beden Eğitimi } \\
\text { ve Spor } \\
\text { Öğretmeni }\end{array}$ & $\begin{array}{c}2001-3000 \\
\text { TL }\end{array}$ & Karate-Do & Evet & 5 & 24 & - & - & 2008 & 1 & 2009 & 1 & - \\
\hline K7 & $\mathrm{K}$ & $18-29$ & Lisans & Bekar & $\begin{array}{l}\text { Beden Eğitimi } \\
\text { ve Spor } \\
\text { Öğretmeni }\end{array}$ & $\begin{array}{l}3001 \text { TL ve } \\
\text { üstü }\end{array}$ & Judo & Hayır & 10 & 18 & & & 2009 & 2 & 2009 & 2 & - \\
\hline K8 & $\mathrm{K}$ & $\begin{array}{l}50 \text { ve } \\
\text { üstü }\end{array}$ & Lisans & Evli & $\begin{array}{c}\text { Beden Eğitimi } \\
\text { ve Spor } \\
\text { Öğretmeni }\end{array}$ & $\begin{array}{l}3001 \text { TL ve } \\
\text { üstü }\end{array}$ & Judo & Hayır & 12 & 19 & 1992 & 3 & 1990 & 5 & 1991 & 2 & - \\
\hline
\end{tabular}




\section{Bulgular}

Araştırma bulguları, katılımcılara yöneltilen sorular dikkate alınarak temalara, bu temalara ait kodlar oluşturulan tablo halinde verilmiştir. Başarı, başarma işi, muvaffakiyet olarak tanımlanmaktadır (Türk Dil Kurumu, 2018). Başarı tanımından yola çıkarak bir sporcunun ulusal ve uluslararası spor organizasyonlarında en üst düzey performansı sergileyerek elde ettiği ve uluslararası spor organizasyonlarında en üst düzey performansı sergileyerek elde ettiği başarı sıralaması, madalya sayısı ve hedeflenen dereceye ulaşabilmektir.

Tablo 2. Sportif başarıyı etkileyen faktörler

\begin{tabular}{|c|c|c|c|c|}
\hline Görüşme sorusu & Alt Tema & Kodlar & Katılımcılar & $\%$ \\
\hline \multirow{4}{*}{$\begin{array}{c}\text { Sportif Başarıyı } \\
\text { Etkileyen Faktörler }\end{array}$} & Fizyolojik fak. & $\begin{array}{l}\text { *Düzenli antrenman } \\
\text { *Düzenli beslenme }\end{array}$ & K1, K2,K5,K6,K7 & $\% 62.5$ \\
\hline & Psikolojik fak. & $\begin{array}{l}* \text { Dinlenme } \\
* \text { Özgüven }\end{array}$ & $\mathrm{K} 1, \mathrm{~K} 2, \mathrm{~K} 3, \mathrm{~K} 5, \mathrm{~K} 7, \mathrm{~K} 8$ & $\% 75$ \\
\hline & Sosyal fak. & $\begin{array}{c}\text { *Özel yaşantı fedakârlığı } \\
\text { *Çevresel destek (aile, antrenör, arkadaş) } \\
\text { *Sabır (azim) }\end{array}$ & $\mathrm{K} 1, \mathrm{~K} 4, \mathrm{~K} 7, \mathrm{~K} 8$ & $\% 50$ \\
\hline & Kişisel fak. & $\begin{array}{c}\text { *Karakter özelliği } \\
\text { *İnanç ve istek (kararlılık) } \\
\text { *Spor ahlakı ve bilinci }\end{array}$ & K1,K2,K3,K5,K7,K8 & $\% 75$ \\
\hline
\end{tabular}

Mega spor organizasyonları katılımcılarının sportif başarıyı etkileyen faktörler sorusuna ilişkin görüşlerinde, fizyolojik, psikolojik, sosyal ve kişisel faktörlerin etkili olduğunu vurgulamışlardır. Görüşlerinden bazıları aşağıda verilmiştir;

- Azim devamlılık ve motivasyon kesinlikle pes etmeden ve aynı kararılıkta çalışmam beni bu serüvene başarılı olmamı sağlayan en büyük etkendir (K3),

- Sportif başarıda en önemlisinin öz güven olduğunu düşünüyorum insan kendisine inanmadan hiçbir şeyi başaramaz ikincisi planlı ve programlı çalışmak baştan salma ve plansız yapılan antrenmanlar kısa vadeli günü birlik başarılar getirir üçüncüsü ise teknikleri çok fazla tekrar yaparak çalışmak olduğunu düşünüyorum (K5). 
Tablo 3. Mega spor organizasyonları kazanımları

\begin{tabular}{|c|c|c|c|c|}
\hline Görüsşme sorusu & Alt Tema & Kodlar & Katılımcılar & $\%$ \\
\hline \multirow{3}{*}{$\begin{array}{c}\text { Mega spor } \\
\text { organizasyonları } \\
\text { kazanımları }\end{array}$} & Sportif kazanımlar & $\begin{array}{ll}\text { Sportif Branşın Tanınması } \\
\text { Sporu Sevdirme } \\
\text { Mesleki Kazanım Başarı } \\
\text { Sportif Erdem } \\
\text { (Kazanma-Kaybetme) } \\
\text { Mücadeleci Ruh }\end{array}$ & $\mathrm{K} 1, \mathrm{~K} 2, \mathrm{~K} 3, \mathrm{~K} 5, \mathrm{~K} 7, \mathrm{~K} 8$ & $\% 75$ \\
\hline & Kişisel Kazanımlar & $\begin{array}{ll}\text { Sosyal Yaşam Becerisi } \\
\text { Trestij Sahibi Olma } \\
\text { Kötü Alıllaşmana } \\
\text { Durma } \\
\text { Fiziksel Sağlık } \\
& \text { Problem Çözme Yetisi }\end{array}$ & $\begin{array}{l}\mathrm{K} 1, \mathrm{~K} 2, \mathrm{~K} 3, \mathrm{~K} 4, \\
\mathrm{~K} 5, \mathrm{~K} 6, \mathrm{~K} 7, \mathrm{~K} 8\end{array}$ & $\% 100$ \\
\hline & Değerler & $\begin{array}{l}\text { Ahlaklı ve Etik Olma } \\
\text { Sağlıklı Birey } \\
\text { Özgüven } \\
\text { Manevi Tatmin } \\
\text { Saygınlık }\end{array}$ & $\begin{array}{l}\mathrm{K} 1, \mathrm{~K} 2, \mathrm{~K} 3, \mathrm{~K} 4, \\
\mathrm{~K} 5, \mathrm{~K} 6, \mathrm{~K} 7, \mathrm{~K} 8\end{array}$ & $\% 100$ \\
\hline
\end{tabular}

Katılımcılar, spor branşının kazanımları sorusuna ilişkin görüşlerinde sportif, kişisel kazanımlar ve değerler olarak belirtmişlerdir. Görüşlerinden bazıları aşağıda verilmiştir;

> Spor bana toplumda nasıl davranılması gerektiğini, insanlarla birebir ilişkilerin geliştirilmesi ve toplumla kaynaşabilmeyi kazandırdı. Yükseldikçe çevremdeki insanlarla saygınlık içinde bir hayat sürmeyi sağladı ve topluma faydalı bir şekilde hizmet etme bilincini yerleştirdi( K2),

Sporun bana kattıkları çok fazla bu hayatta yaptığım belki de en güzel şey bu spor. Her spor gibi judonun da bana kattıkları saymakla bitmez. Öncelikle şuan yaptığım mesleğimi yanı beden eğitimi öğretmenliğini kazandırdı. Tüm hayatım boyunca hep sevilen saygı duyulan bir insan olmamı sağladı. Küçük yaşlardan itibaren hayatımı kazanmamı aileme ve çevremdeki insanlara maddi manevi destek olmamı sağladı. Judonun verdiği öz güven ve judo disiplini sayesinde her zaman kendimi kolaylıkla ifade edebildim. Çevremdeki insanların saygınlığını kazandım. Okul dışındaki tüm hayatımı bir sporcu olarak yaşamamı sağladı beslenme dinlenme eylenmelerimi antrenman programıma göre ayarlamamı kötü alışkanlıklardan uzak durmayı ve iyi arkadaşlıklar edinmemi sağladı. Judo sayesinde başarmanın gurunu yaşadım, emeğimin değerini anladım. Sabrı öğrendim, geçirdiğim sakatılar sayesinde bedenimin değerini anladım. Millî sporcu olmam bana hayatımın her alanında pozitif ayrımcılık kattı. Mesleğimde başarılıysam buda en büyük kattı sporumdur. Judo benim tüm hayatımı düzene soktu attığım her adımda sporcu gibi yaşamam gerektiğini öğreterek daha kaliteli bir yaşam sundu bana (K7). 
Tablo 4. Mega spor organizasyonları katılımcılarının öz-farkındalık algıları

\begin{tabular}{|c|c|c|c|c|}
\hline Görüşme sorusu & Alt Tema & Kodlar & Katılımcilar & $\%$ \\
\hline \multirow[t]{2}{*}{$\begin{array}{c}\text { Öz-farkındalık } \\
\text { Düzeyi }\end{array}$} & $\begin{array}{l}\text { Müsabaka öncesi } \\
\text { Öz-farkındalık }\end{array}$ & $\begin{array}{ll} & \text { Performans değerlendirme } \\
& \text { Fiziksel hazırlık değerlendirme } \\
& \text { Psikolojik hazırlı süreci (stres } \\
\text { kontrolü, odaklanma, istek\& } & \\
\text { motivasyon) } \\
\text { Kişisel raporlar }\end{array}$ & $\begin{array}{l}\mathrm{K} 1, \mathrm{~K} 2, \mathrm{~K} 3, \mathrm{~K} 4, \\
\mathrm{~K} 5, \mathrm{~K} 6, \mathrm{~K} 7, \mathrm{~K} 8\end{array}$ & $\% 100$ \\
\hline & $\begin{array}{c}\text { Müsabaka } \\
\text { sonrası } \\
\text { Öz-farkındalık }\end{array}$ & $\begin{array}{ll}\text { Fiziksel sürdürülebilirlik } \\
\text { Performans değerlendirme } \\
\text { Yenilik arayışı } \\
\text { Kişisel rapor analizi }\end{array}$ & $\mathrm{K} 1, \mathrm{~K} 2, \mathrm{~K} 3, \mathrm{~K} 5, \mathrm{~K} 7$ & $\% 62.5$ \\
\hline
\end{tabular}

Katıımcılar, müsabaka öncesi ve müsabaka sonra öz-farkındalık düzeylerine ilişkin soruya müsabaka öncesi öz-farkındalık algısı; performans değerlendirme, fiziksel hazırlık değerlendirme, psikolojik hazırlık süreci ve kişisel raporlarla tespit ettiklerini, müsabaka sonrası öz-farkındalık algıları ise; fiziksel sürdürülebilirlik, performans değerlendirme, yenilik arayışı ve kişisel rapor analizleri olarak belirtmişlerdir. Görüşlerinden bazıları aşağıda verilmiştir;

Müsabaka öncesinde şampiyon bir sporcu olarak özelliklerimin ve neler yapmam gerektiğinin bilincinde müsabakaya çıkıyorum. Zaten iyi hazırlandıysam müsabaka öncesinde vücudum bana iyi olduğumu söyler ve psikolojim bu yönde olumlu olur ve inanmış bir şekilde müsabaka çıkarım. Müsabaka sonrasında ise eğer şampiyon olduysam bir an önce yine antrenmanlara başlarım ve kendime yeni özellikler katmaya çalışırım (K1).

> Evet, değerlendiririm bunu çoğu zaman yazarak yaparım, düzenli olarak tuttuğum bir günlüğüm vardır, mutlaka maçların hazırlık evrelerinde neler yaptığımı neler düşündüğümü en çokta neler hissettiklerimi yazarım. Maçta neler yapmalıyım nelere dikkat etmeliyim bu maçın ne kadar önemli olduğu vs. maçlar bittikten sonrada yazarım neler hissettiğimi ne kadarını yapabildiğimi daha sonra neler yapmam gerektiğini. Bu benim bir nevi konsantre olma yöntemimdir. Kendi kendimi maça motive etme başarabileceğime inandırma ve farkındalığımı artırma yöntemimdir. Maçtan sonra ise güzel geçmişse yaşadığım gururu yazarım neyi daha iyi yaptığımı ya da neleri düzeltmen gerektiğine bakarım. Eğer maçım başarısız geçmişse veya sakatlanmışsam duyduğum aşırı üzüntüyü kendimi rahatlatmak için yazarım sonra vaz geçmemek için nedenlerimi sıralarım kendimi hırslandırmaya tabiri caizse gaza getirmeye çalışırım bir sonraki maç için kendimi normale döndürmeye çalışırım her şey güzel olacak diye kendimle konuşurum çünkü başarısızıkla sonuçlanan maçlarım benim sadece judo hayatımı değil 
normal hayattaki kalitemi de düşürürdü bunu engelleye bilmek adına kötü durumların yerine iyileştirebileceğim şeyleri düşünmeye odaklanırım (K7).

Tablo 5. Olimpik hareket ve Olimpizm anlayışının sürdürülebilirliği

\begin{tabular}{|c|c|c|c|c|}
\hline Görüssme sorusu & Alt Tema & Kodlar & Katılımcılar & $\%$ \\
\hline \multirow{3}{*}{$\begin{array}{l}\text { Olimpik Hareket ve } \\
\text { Olimpizm } \\
\text { Anlayışının } \\
\text { Sürdürülebilirliği }\end{array}$} & Eğitim faaliyetleri & $\begin{array}{ll}\text { Rol model olma } \\
\text { Söyleşi, konferans } \\
\text { Ders içerikleri } \\
\text { Kilimsel destek } \\
\text { Kişel gelişim }\end{array}$ & K1,K2,K6,K7,K8 & \%62.5 \\
\hline & $\begin{array}{c}\text { Sporun } \\
\text { yaygınlaştırılmas1 } \\
\text { faaliyetleri }\end{array}$ & $\begin{array}{l}\text { Reklam, Tutundurma } \\
\text { Olimpik sporcuların desteklenmesi } \\
\text { Değerler }\end{array}$ & $\begin{array}{c}\mathrm{K} 1, \mathrm{~K} 3, \mathrm{~K} 4, \mathrm{~K} 5, \mathrm{~K} 7, \mathrm{~K} \\
8\end{array}$ & $\% 75$ \\
\hline & Spor Örgütleri & $\begin{array}{l}\text { Federasyon eğitimi } \\
\text { Aktif sporcu eğitmen desteği } \\
\text { Spor-siyaset desteği }\end{array}$ & K1,K6,K7,K8 & $\% 50$ \\
\hline
\end{tabular}

Katılımcılar, Olimpik hareket ve Olimpizm anlayışının sürdürülebilirliğine ilişkin soruya görüşlerini eğitim faaliyetleri, sporun yaygınlaştırılması faaliyetleri ve spor örgütleri aracılığıyla sürdürülebilirliğin olabileceğini belirtmişlerdir. Görüşlerinden bazıları aşağıda verilmiştir;

Olimpiyatlar her sporcunun en büyük hayalidir. Olimpiyatlar dünyadaki en büyük spor organizasyonudur. Bu anlamda da olimpiyatların ve olimpizm ruhunun ülkemizde de iyi anlamda anlatılıp öneminin kavranması gerekir. Biz de birçok ilkokul, ortaokul ve lise de öğrencilerle söyleşi yaparak olimpiyatların öneminden bahsediyoruz. Onlara olimpik ruhu aşılamaya çalışıyoruz (K1),

Olimpiyatlara katılmış ve madalya almış sporcuların hangi yönde gelişmek istedikleriyle alakalı çalışma yapılıp yabancı dil, çalıştırıcı ve hakem eğitimlerine federasyonların veya devletin destek vermesi gerektiğini düşünüyorum. Yabancı dili hala yeterli olmasa da kendi imkânlarımla öğrenmeye çalıştım. Eminim bu şekilde yönlendirilmeler yapılsaydı şu anda Türk sporu çok daha farklı yerlerde olabilirdi. Güç ve mevkiye göre gelişimler sağlanmamalıdır. Başarılı birçok sporcunun bugün sporun içinde aktif olarak bulunmadığını düşünüyorum. İşi bilen, yarışmış, bu duyguları tatmış sporcuların takımların başında olması gerekiyor (K8).

\section{Tartışma ve Sonuç}

Mega spor organizasyonları katılımcılarının sportif başarıyı etkileyen faktörler sorusuna ilişkin görüşlerinde, fizyolojik, psikolojik, sosyal ve kişisel faktörlerin önemli olduğu ortaya çıkmıştır. Bu faktörlerin de düzenli antrenman, düzenli beslenme, 
dinlenme, özgüven, özel yaşantılarından fedakârlık, çevresel destek, sabır, karakter özelliği, inanç-istek, spor ahlakı ve spor bilinci ile ilişkili olduğunu belirtmişlerdir.

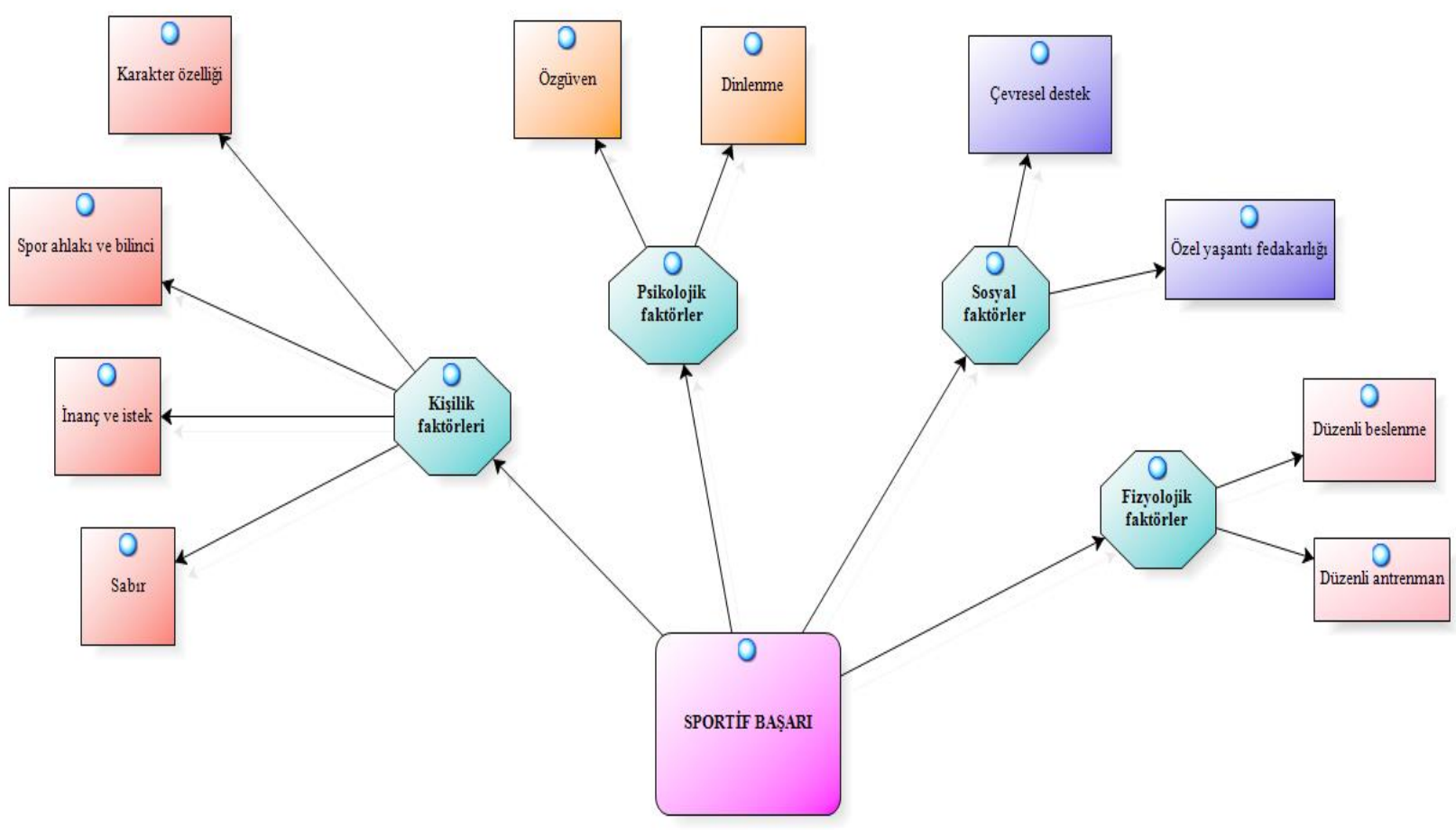

Model 1: Sportif başarıyı etkileyen faktörler

Sporcuların fiziksel ve fizyolojik özellikleri üzerinde yapılan çalışmalarda büyük bir artış görülmesinin en önemli nedenlerinden biri başarının, performansı belirleyen unsurlarla, fiziksel ve fizyolojik özelliklerin direk ilişkili olmasından kaynaklanmaktadır (Aydaş, 2000).

Katılımcılar, Olimpik spor branşının kazanımları sorusuna ilişkin görüşlerinde sportif, kişisel kazanımlar ve değerler olduğunu belirtmişlerdir. 


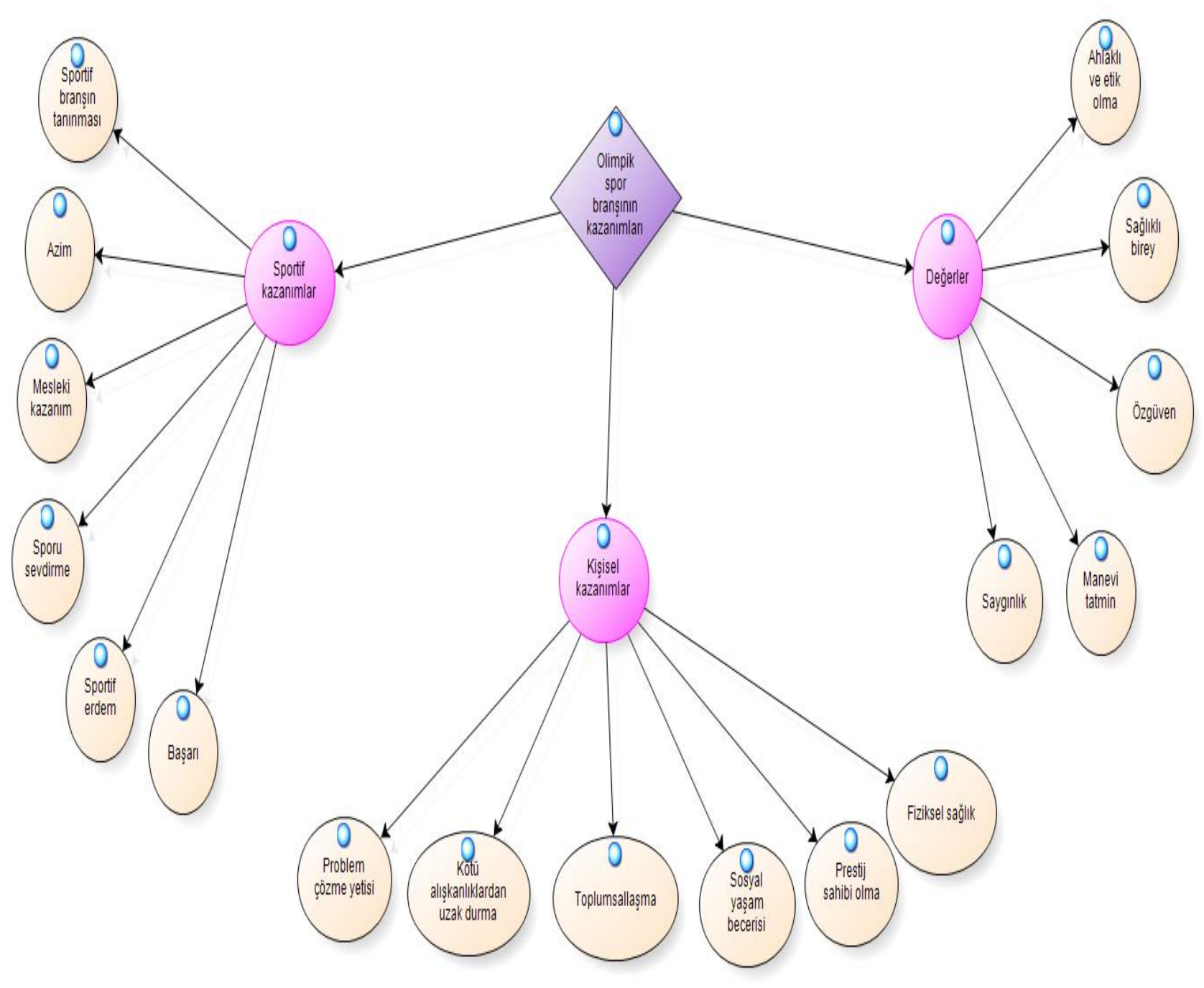

Model 2: Mega spor organizasyonları kazanımları

Olimpizm spor yarışmalarından daha öte bir kavram olup değerler ve idealler bütünüdür Yapılan bu araştırma sonuçlarında da katılımcı görüşleri ile de desteklendiği gibi uluslararası spor organizasyonları ile gelişim gösteren bu değerlerden bazıları arkadaşlık, fair play, barış, dayanışma, eşitlik, anlayış, insanlara ve kurallara saygı, dürüstlük olarak karşımıza çıkmaktadır (IOA, 2006).

Mega spor organizasyonları katılımcıları, müsabaka öncesi ve müsabaka sonra öz-farkındalık düzeylerine ilişkin soruya müsabaka öncesi öz-farkındalık algısı; performans değerlendirme, fiziksel hazırlık değerlendirme, psikolojik hazırlık süreci ve kişisel raporlarla tespit ettiklerini, müsabaka sonrası öz-farkındalık algılarını ise; fiziksel sürdürülebilirlik, performans değerlendirme, yenilik arayışı ve kişisel rapor analizleri olarak belirtmişlerdir. 


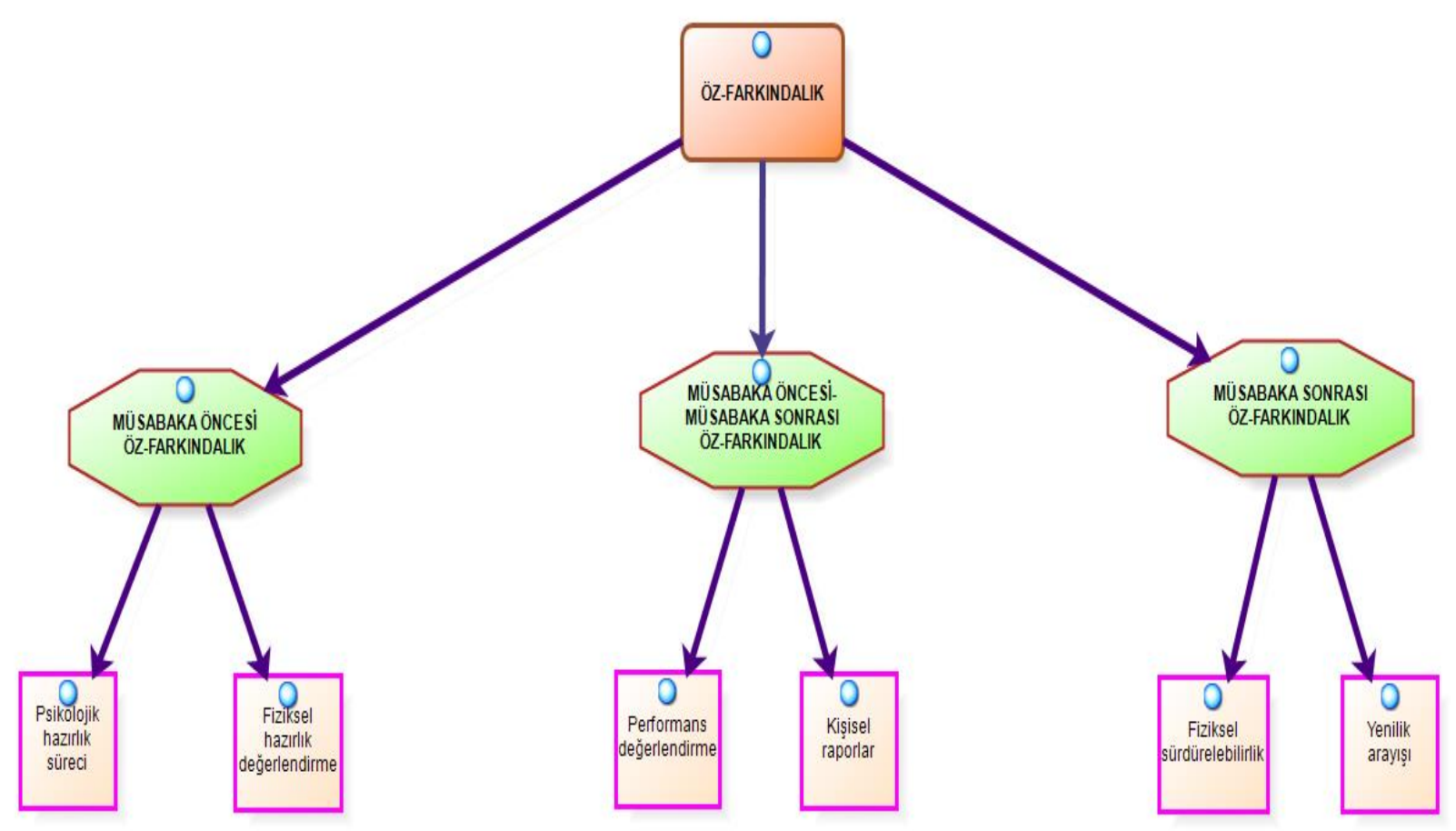

Model 3: Mega spor organizasyonları katılımcılarının öz-farkındalık algıları

Öz-farkındalık kişinin kendi duygularını, düşüncelerini, isteklerini gerçekçi bir biçimde ele alması ve kendisi ile ilgili güçlü ve zayıf yönlerini bilmesi (Kernis, 2003), anlık neler hissettiğimizi bilme, yeteneklerimiz hakkında gerçekçi bir değerlendirme ve yerinde bir öz-güven algısıdır (Elias ve Moceri, 2012). Mega Spor organizasyonu katılımcılarının da müsabaka öncesi ve müsabaka sonrası öz-farkındalık düzeylerinin performanslarındaki başarılarının sürdürülebilirliğine katkı sağladığı düşünülmektedir. Bireyin kendi güçlü ve zayıf yanlarının yenilenmesinde, güçlendirilmesinde var olan özfarkındalık düzeyleriyle ilişkilendirilmektedir.

Mega spor organizasyonları katılımcıları, Olimpik hareket ve Olimpizm anlayışının sürdürülebilirliğine ilişkin soruya görüşlerini eğitim faaliyetleri, sporun yaygınlaştırılması faaliyetleri ve spor örgütleri aracılığıyla sürdürülebilirliğin olabileceğini belirtmişlerdir. 


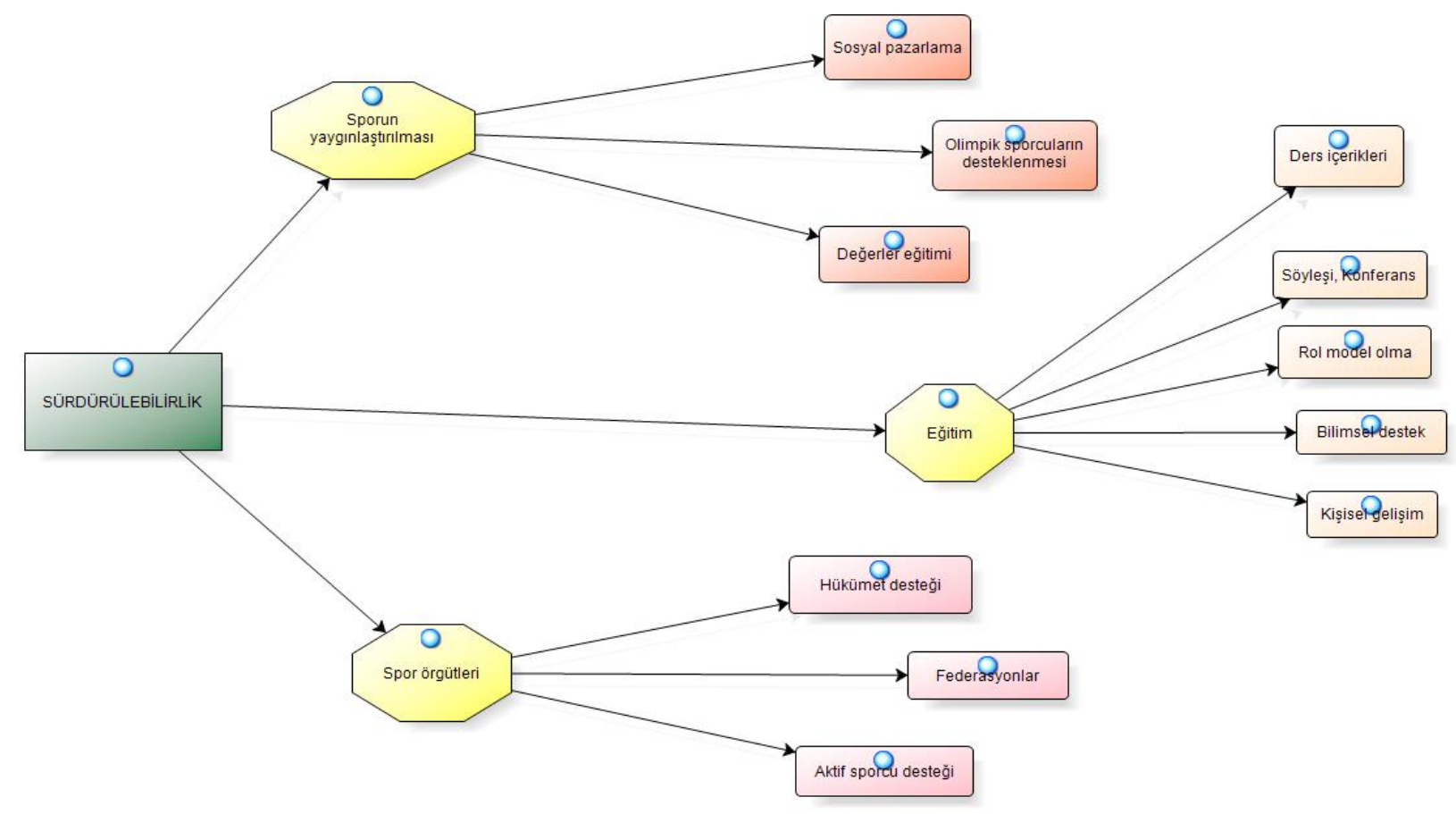

Model 4: Olimpik hareket ve Olimpizm anlayışının sürdürülebilirliği

Olimpik Değerler aynı zamanda Olimpik Hareketin ilkeleri olan evrensellik, sürdürülebilirlik ve ayrımcılık gözetmeme ilkesi gibi değerleri de yaşamımızın bir parçası halinde getirme çabasındadır. Spor olgusu bu durumu gerçekleştirebilecek evrensel bir dildir (Salaheldeen, 2010: 278) ve gerek sportif etkinlikler gerekse bu etkinlikleri düzenleyen spor örgütleri sürdürülebilirliği sağlayarak bu amaca da hizmet etmiş olmaktadırlar.

Olimpik hareket ve anlayışın sürdürülebilirliğinin sağlanmasında eğitim faaliyetleri aracııı̆ıyla halkın, ailelerin ve sporcuları bilinçlendirecek söyleşi, konferans ve bilimsel yayınlarla özellikle kitle iletişim araçlarıyla olimpik sporcuların tanıtılması, deneyim paylaşımlarının yapılması hem branşlara hem de çocuk ve gençlere spor kültürü aşılanmasında farkındalık yaratacağı düşünülmektedir. Farkındalık eğitimlerinin federasyonlar, alanında uzman akademisyenler tarafından hedef kitleye göre sporcuların, çocukların ve gençlerin bilinçlenmesine yönelik programların olimpizm ve olimpik hareketin sürdürülebilmesi için planlamaların yapılması gerekmektedir.

Sonuç olarak; Olimpik Hareket ve Olimpizm düşüncesinin değişen ve gelişen anlamının değerlendirilmesi ve bu düşüncenin yaygınlaştırılması spor kültürünün oluşumunda rol oynamaktadır. Bu bakımından Türkiye'de spor kültürünün sürdürülebilir bir yaşam biçimi haline dönüşmesini sağlamada ülkemizi temsil eden milli sporcuların 
topluma ışık tutması gerekliliği ve önemi görülmektedir. Öz-farkındalığı yüksek olduğu görülen elit sporcuların bu konuda aktif rol almaları adına çalışmalar yapılması önerilmektedir.

\section{Kaynaklar}

Aydaş, F. (2000). A millî boks takımı ile diğer boksörlerin seçilmiş fiziksel ve fizyolojik özelliklerinin karşılaştırılması. Yüksek Lisans Tezi, Ankara Üniversitesi, Sağlık Bilimleri Enstitüsü, Ankara.

Kerkez, F. İ. (2012). Sağlıklı büyüme için okulöncesi dönemdeki çocuklarda hareket ve fiziksel aktivite. Spor Bilimleri Dergisi, 23(1), 34-42.

Bayar, P. (2003). Spor yapan ve yapmayan bayanların kişilik özelliklerinin karşılaştırılması. Spor Bilimleri Dergisi, 14(3), 133-143.

Bora, A. (2012). Bir millî vazife olarak spor ve kadınlar. Spor Bilimleri Dergisi, 23(4), 220 226.

Cohen, R. J., \& Swerdlik, E. M. (2002). Psychological testing and assesment. New York: McGraw-Hill Book Co.

Elias, M.J. and Moceri, D.C. (2012). Developing social and emotional aspects of learning: the American experience. Research Papers in Education, 27(4), 423-434.

Güzel P., Özbey S., Atalay Noordegraff M. (2012). Olimpik eğitimin yaygınlaştırılmasında üniversite oyunlarının etkileri. Uluslararası İnsan Bilimleri Dergisi [Bağlantıda]. 9(1), p:298. Erişim: http://www.insanbilimleri.com

IOA (2006). International Olympic Academy, 46th International Session For Young Participants, Consolidated Report (Workshop), Ancient Olympia- Greece, 2006.

IOC (2004). International Olympic Commitee, Published by the IOC, The Olympic Movement, Chateau de Vidy, 1007 Lausanne, Switzerland, p: 17-21

TMOK (Türkiye Milli Olimpiyat Komitesi). (2002). Tanıtım Kitapçığı, TMOK, İstanbul.

Kernis, M.H. (2003). Toward a conceptualization of optimal selfesteem. Psychological Inquiry, 14(1), 1-26.

Noordegraaf, Atalay, M. (2017) Olimpizm ve olimpik hareket, Edt. Doç. Dr. Selhan ÖZBEY, Nobel Akademik Yayıncılık Eğitim Danışmanlık Tic. Ltd. Şti. Ankara.

Özbey, S. ve Güzel, P. (2009). Olimpik Değerler ve Olimpiyat Oyunlarının Değişen Yüzü, Yeni Dünya Düzeninde Olimpizm Sempozyumu, Ankara.

Roche, M. (2000). Mega-Eventsand Modernity: Olympics and expos in the growth of global culture. London: Routledge,1-29 
Doğanay, A., Ataizi, M., Balaban Salı, J.ve Akbulut, C. (2012) Sosyal Bilimlerde Araştırma Yöntemleri, (1.Basım), Eskişehir, Web Obset.

Türnüklü, A. (2000). Eğitim Bilim Araştırmalarında Etkin Olarak Kullanılabilecek Nitel Araştırma Tekniği: Görüşme. Kuram ve Uygulamada Eğitim Yönetimi, 24, 543-559

Türk Dil Kurumu (2018) Erişim tarihi: 11.05.2018 Erişim adresi: http://www.tdk.gov.tr/index.php?option=com_gts\&kelime=BAŞARI

Ünver, G., Bümen, N. T. ve Başbay, M. (2010). Ortaöğretim alan öğretmenliği tezsiz yüksek lisans derslerine öğretim elemanı bakışı: ege üniversitesi örneği. Eğitim ve Bilim Dergisi, 155 (35), 63- 77.

Salaheldeen, H. M. (2010). Olympic Values and Multiculturalism, IOA, 17th International Seminar on Olympic Studies for Postgraduate Students, 1-30 July, 2009, Olympia, Published by The International Olympic Committee and International Olympic Academy, p: 278.

Silverman, D. (2001). Interpreting qualitative data: Methods for analyzing talk, text and interaction. London: SAGE Publication.

Yıldırım, A. ve Şimşek, H. (2003). Sosyal Bilimlerde Nitel Araştırma Yöntemleri. Ankara: Seçkin Yayınları

Yıldırım, A. ve Şimşek, H. (2005). Sosyal Bilimlerde Nitel Araştırma Yöntemleri. Ankara: Seçkin Yayıncılık. 